\title{
Anthrovision
}

Vaneasa Online Journal

$1.1 \mid 2013$

Varia

\section{Sensate, A Journal for Experiments in Critical Media Practice}

Website review

\section{Steffen Köhn}

\section{OpenEdition}

\section{Journals}

Édition électronique

URL : http://journals.openedition.org/anthrovision/514

DOI : 10.4000/anthrovision.514

ISSN : 2198-6754

Éditeur

VANEASA - Visual Anthropology Network of European Association of Social Anthropologists

Référence électronique

Steffen Köhn, «Sensate, A Journal for Experiments in Critical Media Practice », Anthrovision [En ligne], 1.1 | 2013, mis en ligne le 01 août 2013, consulté le 22 septembre 2020. URL : http://

journals.openedition.org/anthrovision/514 ; DOI : https://doi.org/10.4000/anthrovision.514

Ce document a été généré automatiquement le 22 septembre 2020.

(c) Anthrovision 


\title{
Sensate, A Journal for Experiments in Critical Media Practice
}

Website review

\author{
Steffen Köhn
}

1 Anthropology concerns itself with experimental modes of knowledge transmission at least since the 'crisis of representation' in the 1980s. Since then, much as been written and thought about the potentials of audio-visual media and (with the advance of digital technologies) hypermedia representation. Most often, however, these discussions remained on the theoretical level and were published in the traditional formats of papers and journal contributions. Sensate (www.sensatejournal.com), a new peerreviewed journal that dedicates itself to "pioneering activities in the digital humanities, scholarly publishing, and innovative media practice" thus consequently tries new ways of circulation. It is a web-based, issueless journal that explicitly aims at audiences beyond the narrow confines of academia. Its content consists not of conventional articles but of multimedia documents: audiovisual ethnographies or media projects that are designed in a nonlinear way to allow varying degrees of user-participation. Much of this material originates from the Harvard sensory ethnography lab, which forms the journal's institutional background. All pieces are provided through a new HTML 5 based publishing platform for interactive storytelling called Zeega. A zeega publication looks a bit like a PowerPoint presentation, only that the slides are not necessarily arranged in a sequential order, thus allowing the user more freedom to navigate through the document. Each slide may contain multimedia-content: text, photos, videos, or sound-files. Aside from the sometimes pretty long loading times (depending on your browser and, of course, internet connection) the navigation is fairly simple. A small map provides an overview of the document's structure and thus serves as a kind of directory. However, I was a bit surprised about some "missing links": the overview map does not allow you to jump directly to particular slides, and it is also not possible to return to the Sensate main page from a zeega document.

2 Five pieces are online so far: Steven Feld offers three of his soundscape compositions: sonic explorations of places in Hiroshima, Copenhagen, and Accra. While these have 
been published before on Feld's record label, the zeega document adds accompanying photographs and an audio-commentary spoken by Feld himself. Jeffrey Schapp and Klara Oehler provide a "multi-media mashup" of Marshall MacLuhan`s classic collaboration with graphic artist Quentin Fiore: The medium is the massage. By juxtaposing quotes, film clips and sound extracts from Jerome Agel's acoustic version of the book, Oehler and Schapp convincingly translate the anarchic character of the work into a new media environment. The remaining works to be found on Sensate so far are all ethnographies of sorts: Ximena Alarcon`s Sounding underground is an acoustic exploration of the metro systems of Mexico City, Paris and London, in which commuters were invited to participate by recording (and reflecting upon) their own sound snippets. This presentation gives only a (less interactive) summary of the original web-project. Revere double exposure by Joana Pimenta is a collage of archive materials and contemporary visual research on the 100 year history of America's first public beach. The most substantial piece, Jen Heuson's Hearing the Hills, explores South Dakota`s Black Hills (home to Mount Rushmore, Wounded Knee and the Badlands national park) as a mythical landscape of American history. Heuston mixes a wide range of materials: touristic representations, snippets from popular culture and historical accounts and even personal memoirs in form of her private photo collection of family trips to the hills. While all the ethnographic pieces succeed in the audiovisual evocation of their subjects, they do not yet offer much in terms of anthropological theory or analysis. Yet one can vividly imagine what zeega can make possible in the future, since the platform is flexible, open-source and easy to use. Sensate thus gives us a highly interesting first impression of the possible future of web-based ethnographic representation.

\section{AUTEUR \\ STEFFEN KÖHN}

PHD-Student, Department of Anthropology and African Studies, Johannes Gutenberg-University Mainz 